\title{
PROPERTIES OF CONCRETE MODIFIED BY AMORPHOUS ALUMINA SILICATE
}

\author{
Džigita NAGROCKIENĖ, Giedrius GIRSKAS, \\ Gintautas SKRIPKIŪNAS, Aurelijus DAUGĖLA
}

Vilnius Gediminas Technical University, Sauletekio al. 11, LT-10223 Vilnius, Lithuania

Received 01 December 2014; accepted 09 December 2014

\begin{abstract}
Concrete is the most widely used building material obtained by hardening the mix made of coarse and fine aggregates, cement as the binding material, and water. The basic properties of concrete depend on the quality and properties of cement, w/c ratio and the homogeneity of compaction. Compressive strength is one of the most important properties of concrete. Materials used: Portland cement CEM I 42.5 R, 0/4 fraction sand, 4/16 fraction gravel, amorphous alumina silicate admixture, polycarboxylate ether-based superplasticizer Muraplast FK 63.30, and tap water. Five compositions of concrete mixes containing 0\%, 2.5\%, $5 \%, 7.5 \%$ and $10 \%$ of amorphous alumina silicate admixture by mass of cement were produced. The article analyses the effect of amorphous alumina silicate on the properties of concrete depending on the admixture content. The results revealed that the compressive strength of concrete after 7 days of curing increased by $7.1 \%$, after 28 days of curing increased by $13.3 \%$ when the amorphous aluminum oxide doped silicate content was increased to $10 \%$. Amorphous alumina silicate admixture added in quantities of up to $10 \%$, increased the density of hardened concrete by $0.75 \%$, and ultrasonic pulse velocity in specimens with the admixture increased up to $2.63 \%$.
\end{abstract}

Keywords: concrete, compressive strength of concrete, admixture, predicted frost resistance, water absorption.

\section{Introduction}

Different types of admixtures are used to control physical and mechanical properties of concrete mixes and hardened cement paste. It is important to analyse the effect of such hardened concrete on physical and mechanical properties of concrete in order to reach the best performance of hardened cement paste.

Mineral admixtures of concrete are natural or technogenic materials in the state of dispersion (mostly inorganic and non-water soluble, and that is the main difference from chemical admixtures), described by particle size smaller than $0.16 \mathrm{~mm}$ (the main difference from aggregates). With the use of mineral admixtures, the compressive strength of concrete with the same or even higher w/c ratio increases (Prokhorov 2004).
Pozzolanic admixtures (zeolites, $\mathrm{SiO}_{2}$ microparticles and others) are some of the most prospective components for the development of innovative building materials, such as ultra-high performance concrete, special concretes able to absorb heavy metals or supress radiation. Added to concrete, such admixtures can reduce the weight of structural elements in buildings without compromising the strength indicators. Zeolite admixtures are widely used for finishing as they produce more even surfaces and the paste settles faster. These admixtures change and enable to accelerate Portland cement hydration process, change its physical and mechanical properties.

$\mathrm{SiO}_{2}$ micro-particles, coal, zeolites and ash were used as cement substitutes (pozzolanic admixtures). 
Zeolites have a high content of active $\mathrm{SiO}_{2}$ and $\mathrm{Al}_{2} \mathrm{O}_{3}$. Silica dioxide and ash, like other pozzolanic materials, can increase concrete strength as a result of $\mathrm{Ca}(\mathrm{OH})_{2}$ reaction with pozzolans. Zeolites, as other pozzolanic materials, increase the strength of concrete more than cement. On the other hand, zeolites also induce the appearance of undesirable products, such as alkali and other complex compounds (Di Sabatino et al. 2011).

According to the studies of A. S. Brykov and coauthors, $\mathrm{SiO}_{2}$ micro-particles used in the cement mix also affect the process of hydration of cement minerals and, thus, the properties of the final product (Brykov et al. 2010).

Researchers found that different types of zeolites act as pozzolanic admixture in concretes, $\mathrm{CSH}$ and $\mathrm{CAH}$ gel phases increase during cement hydration, and these gel phases improve the resistance of cement mixes to acids and sulphate corrosion (Janotka, Krajči 2000).

Synthetic zeolites are obtained by heating the suspensions of alkaline alumina silicate mixes, namely, the mixes containing $\mathrm{SiO}_{2}, \mathrm{Al}_{2} \mathrm{O}_{3}$, alkali and water. Zeolites can be synthesized from crystal or amorphous materials, alumina silicate or alkali metals.

P. Thuadaij with co-authors obtained Na-x zeolite from fly ash. The ash was mixed with caustic soda. The obtained mixes were melted at $823 \mathrm{~K}$ temperature (Thuadaij, Nuntiya 2011).

X. Querol with co-authors conducted tests with coal combustion ash. The results showed that synthesis products contained analcime, zeolite $\mathrm{Na}-\mathrm{Pl}$ and phillipsite (Querol et al. 1997).

F. Canpolat with co-authors tested concrete with active mineral admixture zeolite. Cement was replaced with zeolite from 5 to $35 \%$ by mass of cement. The researchers also studied the effect of zeolite admixture and fly ash on the strength properties of concrete. Fly ash was added at $5 \%$ by cement mass. The compressive strength was measured after 2, 7, 28 and 90 days of curing. The test results showed that the highest compressive strength after 28 days of curing was achieved when $20 \%$ zeolite was used; the optimal contents of fly ash used in combination with zeolite were $10-25 \%$ zeolite and 5\% fly ash (Canpolat et al. 2004).

Latvian researchers studied the compressive strength of regular concrete with Centrilit NC admixture after 7, 28 and 155 days of curing. After 7 days of curing, concrete specimens with pozzolanic admixture demonstrated $15.2 \%$ higher compressive strength compared with control sample; after 28 days of curing in water the compressive strength increased more than 4 times, i.e. $26.38 \%$. Afterwards, the specimens were cured for 127 days at $20{ }^{\circ} \mathrm{C}$ temperature. After 155 days of curing, the compressive strength of specimens without the admixture was $61.1 \mathrm{MPa}$ and $67.4 \mathrm{MPa}$ in specimens with the admixture (Justs et al. 2011)

Researchers have conducted detailed studies with catalysts used in the oil industry. The catalysts contain silica dioxide and aluminium oxide and act as pozzolanic admixtures. J. Paya and co-authors also used catalyst waste in concrete mixes and found that compressive strength of specimen containing up to $20 \%$ of catalyst waste was higher than in control specimens (Paya et al. 1999).

The aim of this paper is to determine the effect of certain amounts of amorphous alumina silicate admixture on the properties of hardened concrete paste.

\section{Concrete raw materials and compositions of tested mixes}

The binding material used in the test was Portland cement CEM I 42.5 R produced by AB Akmenès cementas in compliance with standard LST EN 197-1:2001 requirements. Portland cement characteristics are presented in Table 1. 0/4 fraction sand complying with LST EN 12620:2003 was used as fine aggregate. 4/16 fraction gravel complying with LST EN 12620:2003 was used as coarse aggregate. Physical properties of sand and gravel are presented in Table 2.

Table 1. Portland cement characteristics

\begin{tabular}{|c|c|c|c|c|}
\hline Class & $\begin{array}{c}\text { Bulk } \\
\text { density, } \\
\mathrm{kg} / \mathrm{m}^{3}\end{array}$ & $\begin{array}{c}\text { Specific } \\
\text { gravity, } \\
\mathrm{kg} / \mathrm{m}^{3}\end{array}$ & $\begin{array}{c}\text { Specific } \\
\text { surface, } \\
\mathrm{g} / \mathrm{cm}^{2}\end{array}$ & $\begin{array}{c}\text { Particle } \\
\text { size, } \mu \mathrm{m}\end{array}$ \\
\hline CEM I 42,5 R & 1200 & 3100 & 3700 & $5-30$ \\
\hline
\end{tabular}

Table 2. Physical properties of gravel and sand

\begin{tabular}{|c|c|c|c|}
\hline \multirow{2}{*}{ Aggregates } & Fraction & Characteristics & $\begin{array}{c}\text { Test } \\
\text { results }\end{array}$ \\
\hline \multirow{2}{*}{ Gravel } & \multirow{3}{*}{$4 / 16$} & Particle density, $\mathrm{kg} / \mathrm{m}^{3}$ & 2300 \\
\cline { 3 - 4 } & & Bulk density, $\mathrm{kg} / \mathrm{m}^{3}$ & 1582 \\
\cline { 3 - 4 } Sand & \multirow{2}{*}{$0 / 4$} & Water absorption, \% & 0.59 \\
\hline & & Particle density, $\mathrm{kg} / \mathrm{m}^{3}$ & 2650 \\
\cline { 3 - 4 } & & Bulk density, $\mathrm{kg} / \mathrm{m}^{3}$ & 1546 \\
\cline { 3 - 4 } & & Water absorption, \% & 1.30 \\
\hline
\end{tabular}


A small amount of super high quality superplasticizer Muraplast FK 63.30 ("MC-Bauchemie") was used to improve the properties of concrete. This superplasticizer speeds up the initial setting and creates high early strength in concrete. This product is used in the production of super strong concretes. Clean tap water without concrete setting supressing admixtures and complying with LST EN 1008:2002 requirements was used for the preparation of concrete mix. Amorphous alumina silicate admixture Centrilit NC ("MC-Bauchemie"), bulk density $1.43 \mathrm{~g} / \mathrm{dm}^{3}$, was added to the concrete mix. 5 batches of concrete mixes were manually produced in laboratory conditions. The batches differed by the content of amorphous alumina silicate admixture ranging from $0 \%$ to $10 \%$ by mass of cement. Compositions of concrete mixes used to produce $1 \mathrm{~m}^{3}$ of concrete are presented in Table 3 .

\section{Research methods}

Concrete mixes were produced manually in the laboratory in metal forms of dimensions $100 \times 100 \times 100 \mathrm{~mm}$. After 24 hours of curing, the specimens were removed from the forms and kept in water at $20 \pm 2{ }^{\circ} \mathrm{C}$ for 28 days. The compressive strength of concrete cubes was measured after 7 and 28 days of curing in water according to the methodology described in LST EN 12390-3:2009.

Density of the specimens was determined according to LST EN 12390-7:2009.

Ultrasonic pulse velocity was determined according to LST EN 12504-4:2004.

Water absorption was determined after 4 days of soaking in water. The specimens were soaked in $20 \pm 5{ }^{\circ} \mathrm{C}$ tap water and kept there until the constant weight was achieved. The specimens must be placed with at least $15 \mathrm{~mm}$ spaces between them and covered with at least $20 \mathrm{~mm}$ of water. The constant weight is achieved when the difference between two weighting results after $24 \mathrm{~h}$ is less than $0.1 \%$. Prior to weighting, the specimens must be dried with a damp cloth to remove the excess water. To determine the kinetics of water absorption, the specimens were soaked in water and weighted after $15 \mathrm{~min}, 30 \mathrm{~min}, 45 \mathrm{~min}, 1$ hour, 2, $3,4,5,6,7,8,24,48,72$, and 96 hours.

Frost resistance of concrete depends both on open porosity (the amount of capillary pores), and on closed porosity (air content in the mixture), and quantitatively can be determined by the frost resistance factor $K F$, which is derived from the equation (Sheikin, Dobshic 1989):

$$
K_{F}=\frac{P_{u}}{0.09 P_{a}},
$$

where: $P_{u}$ is closed porosity of concrete; $P_{a}$ is open porosity of concrete.

When frost resistance factor $K F$ is known, the frost resistance of the conglomerate can be predicted using the function of conglomerate frost resistance and frost resistance factor $K F$ (Skripkiūnas 2007).

\section{Analysis of test results}

Concrete density was determined by testing. The test results are presented in Figure 1.

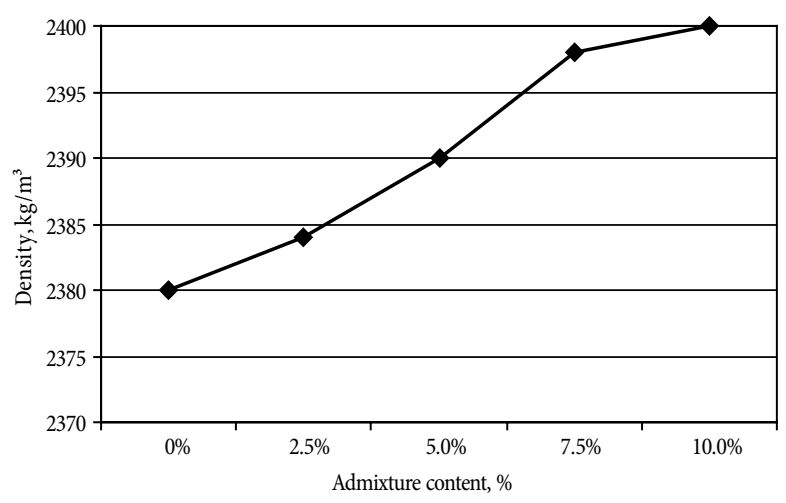

Fig. 1. Relation between density and amorphous alumina silicate admixture content

Table 3. Compositions of $1 \mathrm{~m}^{3}$ of concrete mix

\begin{tabular}{|c|c|c|c|c|c|c|c|c|}
\hline $\begin{array}{c}\text { Admixture } \\
\text { content, } \%\end{array}$ & Cement, kg & Gravel, kg & Sand, kg & Centrilit NC, kg & Water, kg & Plasticizer, kg & W/C & $\begin{array}{c}\text { Slump } \\
\text { class }\end{array}$ \\
\hline 0 & 371 & 811 & 1158 & 0 & 130 & 1.855 & 0.45 & $\mathrm{~S} 1$ \\
\hline 2.5 & 361.7 & 811 & 1158 & 9.3 & 130 & 1.855 & 0.45 & $\mathrm{~S} 1$ \\
\hline 5.0 & 352.5 & 811 & 1158 & 18.6 & 130 & 1.855 & 0.45 & $\mathrm{~S} 1$ \\
\hline 7.5 & 343.2 & 811 & 1158 & 27.9 & 130 & 1.855 & 0.45 & $\mathrm{~S} 1$ \\
\hline 10.0 & 333.9 & 811 & 1158 & 37.1 & 130 & 1.855 & 0.45 & $\mathrm{~S} 1$ \\
\hline
\end{tabular}


According to the test results, the highest density of $2400 \mathrm{~kg} / \mathrm{m}^{3}$ was recorded in the batch of specimens containing $10 \%$ of amorphous alumina silicate admixture, and the lowest density of $2380 \mathrm{~kg} / \mathrm{m}^{3}$ was observed in the batch without amorphous alumina silicate admixture. The function in Figure 1 illustrates that density increases with higher content of the admixture in the cement paste. Concrete densities differ insignificantly. The biggest difference in densities of $0.75 \%$ was observed in specimens containing the admixture Centrilit NC. The recorded highest density of these specimens was $18 \mathrm{~kg} / \mathrm{m}^{3}$. The test revealed that concrete density increases with the addition of amorphous alumina silicate admixture.

Figure 2 illustrates the relationship between the compressive strength and the curing time of 7 and 28 days.

As seen from Figure 2, the highest compressive strength after 7 days of curing in specimens containing Centrilit NC admixture is $72.10 \mathrm{MPa}$. This value was achieved by adding $10 \%$ amorphous alumina silicate admixture to the concrete mix. The lowest compressive strength is observed in specimens without the admixture. The difference between the highest and lowest compressive strength values is $4.8 \mathrm{MPa}$, i.e. $7.1 \%$.

After 28 days of curing, the highest compressive strength of concrete containing amorphous alumina silicate admixture was 79.4 MPa and the lowest value was $70.1 \mathrm{MPa}$ (Fig. 2). The amorphous alumina silicate admixture content was $10 \%$ and $0 \%$, respectively. The difference between the values is $9.3 \mathrm{MPa}$, i.e. the increase of $13.3 \%$. The analysis of results (Fig. 2) revealed that higher content of amorphous alumina silicate admixture increases the compressive strength of concrete after 7 and 28 days of curing.

Ultrasonic pulse velocity in the specimens was measured after 7 and 28 days of curing (Fig. 3).

After 7 days of curing, the highest ultrasonic pulse velocity of $4730 \mathrm{~m} / \mathrm{s}$ was observed in concrete specimens containing $10 \%$ of Centrilit NC admixture. The lowest value of $4609 \mathrm{~m} / \mathrm{s}$ was observed in specimens without amorphous alumina silicate admixture. The analysis of the test results revealed that after 7 days of curing, the ultrasonic pulse velocity in specimens containing amorphous alumina silicate admixture increased by $2.63 \%$.

After 28 days of curing, the highest ultrasonic pulse velocity of $4930 \mathrm{~m} / \mathrm{s}$ was observed in specimens containing $10 \%$ of amorphous alumina silicate ad- mixture. The lowest value of $4735 \mathrm{~m} / \mathrm{s}$ was observed in specimens without the admixture. The analysis of results (Fig. 3) revealed that after 28 days of curing, the ultrasonic pulse velocity in specimens containing amorphous alumina silicate admixture increased by $4.11 \%$. Ultrasonic pulse velocity increases with higher amorphous alumina silicate admixture content.

Water absorption was measured after 4 days of soaking (Fig. 4).

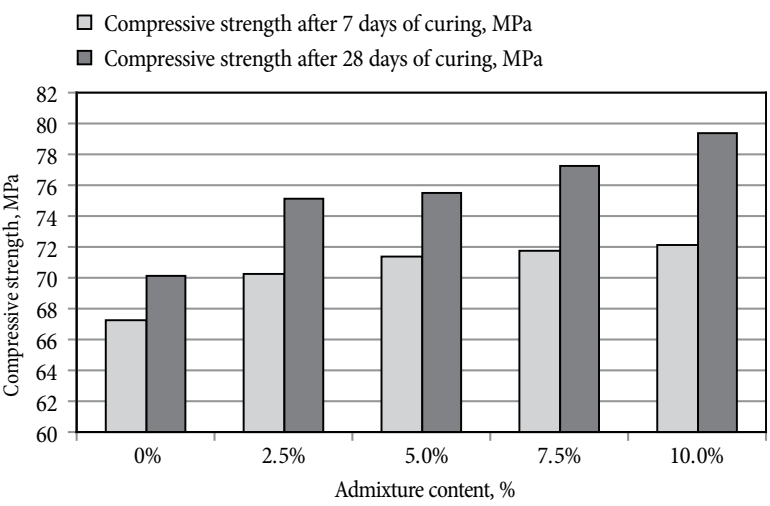

Fig. 2. Function of compressive strength after 7 and 28 days of curing and amorphous alumina silicate admixture content

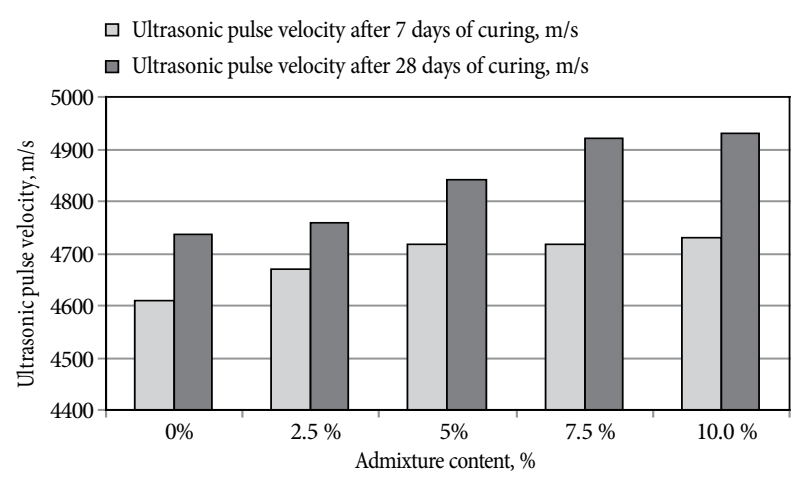

Fig. 3. Function of ultrasonic pulse velocity and amorphous alumina silicate admixture content

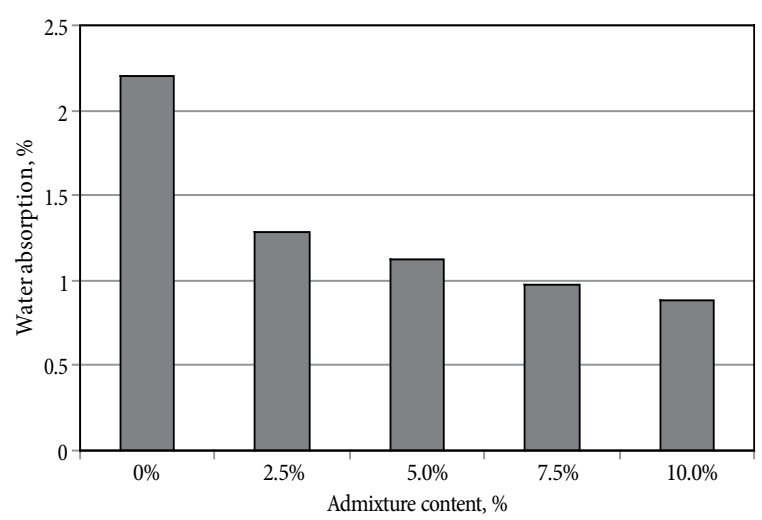

Fig. 4. Function of water absorption and amorphous alumina silicate admixture content 
The highest water absorption was observed in control specimens and the lowest water absorption of $0.88 \%$ was observed in specimens containing $10 \%$ of amorphous alumina silicate admixture. A drop in water absorption amounting to $2.32 \%$ was observed when the highest amount of amorphous alumina silicate admixture was added. Higher content of amorphous alumina silicate admixture reduces water absorption of concrete.

To determine the kinetics of water absorption (Fig. 5), the specimens were soaked in water and weighted after $15 \mathrm{~min}, 30 \mathrm{~min}, 45 \mathrm{~min}, 1$ hour, 2, 3, 4, $5,6,7,8,24,48,72$, and 96 hours.

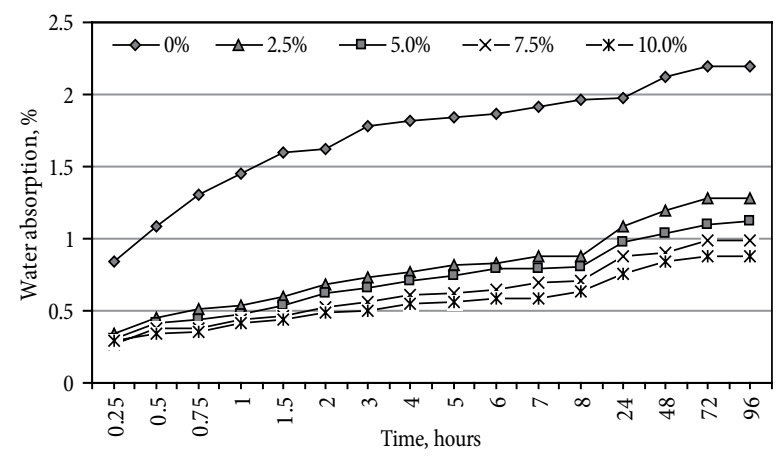

Fig. 5. Kinetics of water absorption

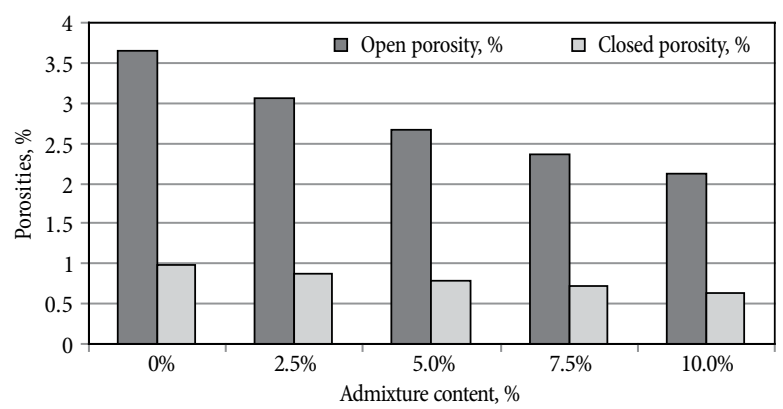

Fig. 6. Function of closed and open porosity and amorphous alumina silicate admixture content

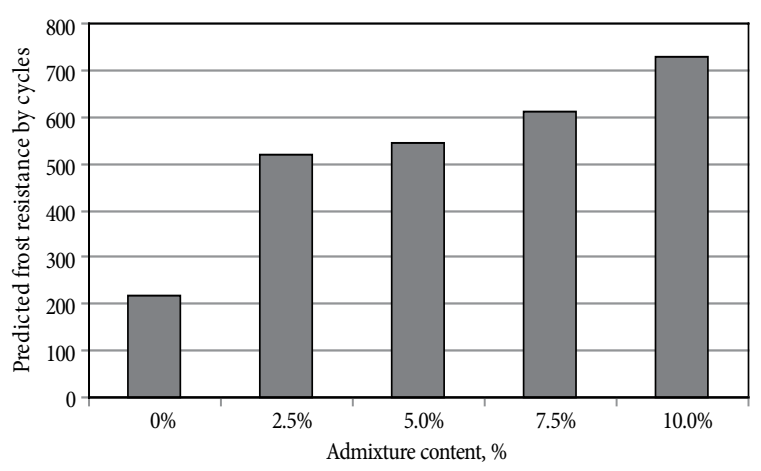

Fig. 7. Function of predicted frost resistance by cycles and amorphous alumina silicate admixture content
The analysis of the function in Figure 5 reveals that at the beginning, water absorption increases every day; and later, the weight settles.

Closed and open porosity of concretes was also tested. The test results are presented in Figure 6.

The test results revealed that higher content of amorphous alumina silicate admixture reduces open porosity. Open porosity in concrete specimens without amorphous alumina silicate admixture was 3.64\%; open porosity reduces by $2.12 \%$ with the highest content of amorphous alumina silicate admixture. The highest open porosity of $0.99 \%$ was observed in control specimens and the lowest open porosity of $0.64 \%$ was determined in specimens containing $10 \%$ of amorphous alumina silicate admixture. The test results also revealed that higher content of amorphous alumina silicate admixture reduces closed porosity.

The predicted frost resistance of concrete by cycles was determined according to the frost resistance factor KF. The function of predicted frost resistance by cycles and amorphous alumina silicate admixture content is presented in Figure 7.

The highest frost resistance was obtained in specimens containing $10 \%$ of admixture and the lowest - in specimens without the admixture, 728 and 219 cycles, respectively. The analysis of results revealed that $10 \%$ of admixture increased the predicted frost resistance of concrete.

The predicted frost resistance of concrete by cycles depends on the content of amorphous aluminosilicate admixture: higher content of the admixture increases the predicted frost resistance of concrete.

\section{Conclusions}

1. The test results revealed that higher content of amorphous alumina silicate admixture increases the compressive strength of concrete; compared with control specimens, the compressive strength of modified concrete after 7 and 28 days of curing increased by $7.1 \%$ and $13.3 \%$, respectively.

2. The test results revealed that the density of concrete modified with amorphous alumina silicate admixture increased by $0.75 \%$ compared to the control specimen; the ultrasonic pulse velocity in modified specimens increased by $2.63 \%$.

3. The highest water absorption of $2.20 \%$ was observed in control specimens and the lowest water absorp- 
tion of $0.88 \%$ was observed in specimens modified with $10 \%$ of amorphous alumina silicate admixture. Higher content of amorphous alumina silicate admixture reduces water absorption, increases frost resistance and durability of concrete.

4. The test results revealed that amorphous alumina silicate admixture increases the predicted frost resistance of concrete; $10 \%$ of admixture increased the predicted frost resistance by 728 cycles.

\section{References}

Brykov, A. S.; Kamaliev, R. T.; Mokeev, M. 2010. Influence of ultradispersed silica on Portland cement hydration, Russian Journal of Applied Chemistry 83(2): 208-213. http://dx.doi.org/10.1134/S1070427210020059

Canpolat, F.; Yilmaz, K.; Kose, M. M.; Sumer, M.; Yurduse, M. A. 2004. Use of zeolite, coal bottom ash and fly ash as replacement materials in cement production, Cement and Concrete Research 34: 731-735. http://dx.doi.org/10.1016/S0008-8846(03)00063-2

Di Sabatino, B.; Gimeno, D.; Pace, C. 2011. Synthesis and characterization of $\mathrm{Na}-\mathrm{X}, \mathrm{Na}-\mathrm{A}$ and $\mathrm{Na}-\mathrm{P}$ zeolites andhydroxysodalite from metakaolinite, ClayMinerals 46: 339-354. http://dx.doi.org/10.1180/claymin.2011.046.3.339

EN 197-1:2001/A1:2004. Cement - Part 1: Composition, specifications and conformity criteria for common cements.

EN 12620:2003+A1:2008. Aggregates for concrete.

EN 1008:2002. Mixing water for concrete - Specification for sampling, testing and assessing the suitability of water, including water recovered from processes in the concrete industry, as mixing water for concrete.

EN 12390-3:2009. Testing hardened concrete - Part 3: Compressive strength of test specimens.
EN 12390-7:2009. Testing hardened concrete - Part 7: Density of hardened concrete.

EN 12504-4:2004. Testing concrete - Part 4: Determination of ultrasonic pulse velocity.

Janotka, I.; Krajči, L. 2000. Utilization of natural zeolite in Portland pozzolan cement of increased sulphate resistance, in Proceedings of 5th CANMET/ACI Conference on Durability of Concrete, 4-9 June 2000, Barcelona, Spain, 223-238.

Justs, J.; Shakhmenko, G.; Bajare, D.; Toropovs, N. 2011. Comparison of pozzolanic additives for normal and high strength concrete, in 8th International Scientific and Practical Conference on Environment, Technology and Resources, 20-22 June 2011, Rezekne, Latvia, II: 79-84.

Paya, J.; Monzo, M.; Borrachero, V. 1999. Fluid catalytic cracking residue (FC3R): an excellent mineral by-product for improving early-strength development of cement mixtures, Cement and Concrete Research 29(11): 1773-1779.

Prokhorov, I. B. 2004. Primenenie mikronapolnitelya v betonakh, Sovremennye naukoemkie tekhnologii 2: 160-161.

Querol, X.; Alastuey, A.; Lopez-Soler, A.; Plana, F.; Andres, J. M.; Juan, R.; Ferrer, P.; Ruiz, C. R. 1997. A fast method for recycling fly ash: microwave-assited zeolite synthesis, Environmental Science and Technology 31(9): 2527-2533. ISSN $1520-5851$.

Skripkiūnas, G. 2007. Statybiniu konglomeratu struktūra ir savybes: vadovèlis. Kaunas: Vitae Litera. 334 p.

Sheikin, A. E.; Dobshic, L. M. 1989. Portland cement concrete with high frost resistance. Leningrad: Stoiizdat. 128 p. (in Russian).

Thuadaij, P.; Nuntiya, A. 2011. Synthesis of Na-x hydrate zeolite from fly ash and amorphous silica from rice husk ash by fusion with caustic soda prior to incubation, in 2011 International Conference on Chemistry and Chemical Process IPCBEE, 2011 May 28-29, Bangkok, Thailand 10: 69-74.

Džigita NAGROCKIENĖ, Assoc. Prof. at the Department of Building Materials, Vilnius Gediminas Technical University (VGTU). PhD (2003). Research interests: concrete properties, concrete durability, concretes with superplasticizers, frost resistance of concrete.

Giedrius GIRSKAS, $\mathrm{PhD}$ student at the Research Institute of Building Materials and Products, Vilnius Gediminas Technical University (VGTU). Research interests: concrete durability, frost resistance of concrete, concrete with additives, synthetic zeolites in concrete.

Gintautas SKRIPKIŪNAS, Prof. at the Department of Building Materials, Vilnius Gediminas Technical University (VGTU). $\mathrm{PhD}$ (1994). Research interests: construction of materials, concrete technology, concrete durability, concrete properties, frost resistance of concrete.

Aurelijus DAUGE்LA, PhD student at the Department of Building Materials, Vilnius Gediminas Technical University (VGTU). Research interests: concrete durability, concrete technology, concrete properties, concrete with additives. 